\title{
Plasma lipid levels in preterm neonates receiving parenteral fat emulsions
}

\author{
J L HILlIARD, D L SHANNON, M A HUNTER, AND Y W BRANS \\ Perinatal Research Laboratory, Department of Pediatrics and Department of Obstetrics and Gynecology, \\ University of Texas Health Science Center at San Antonio, USA
}

SUMMARY Concentrations of various plasma lipid fractions were determined during 96 hours of continuous parenteral infusions of lipid emulsions in 10 normally-grown neonates whose birthweights ranged from 960 to $1760 \mathrm{~g}$ and whose gestational ages ranged from 26 to 32 weeks. Total lipid, triglyceride, free glycerol, and free fatty acid concentrations were measured. During lipid infusions, mean plasma concentrations of all lipid fractions increased above the mean preinfusion values if $2 \mathrm{~g} / \mathrm{kg}$ a day or more of lipid emulsion was used. There were no further significant increases in mean plasma lipid levels if the infused dosage was increased to 3 or $4 \mathrm{~g} / \mathrm{kg}$ a day. At these higher infusion rates however, there were considerable individual variations. The only neonate less than 27 weeks of gestation had plasma lipid levels severalfold higher than any of his peers, his plasma was frankly creamy on visual inspection, and the study had to be stopped. Further investigations are needed to determine the optimal modalities of parenteral nutrition with fat emulsions.

Parenterally administered fat emulsion particles are metabolised in a similar manner as natural chylomicrons. ${ }^{1}$ Increases in plasma lipid concentrations have been documented in low birthweight neonates receiving various doses of fat emulsions parenterally. ${ }^{2-9}$ Available data suggest that preterm neonates may not clear fat emulsion particles from their plasma as quickly as older children or adults. There is concern therefore, regarding potential adverse effects related to alterations in plasma lipid patterns. ${ }^{79-12}$ Unfortunately, most studies of lipid tolerance have been performed after bolus injections $s^{2} 8$ or short-term infusions ${ }^{4579}$ and it is not clear whether the results may be extrapolated to long-term infusions as used in clinical practice. As an initial step towards answering this question, plasma lipid patterns were determined in a group of normally-grown preterm neonates receiving a fat emulsion infusion continuously at a steady rate.

\section{Materials and methods}

Ten neonates less than $1800 \mathrm{~g}$ were studied with their parents' consent. The study protocol was approved by the Institutional Review Board. Birthweights were recorded to the nearest $10 \mathrm{~g}$. Gestational age was determined from the mother's menstrual history, checked in most cases by sonographic determination of the fetus' biparietal diameter, and confirmed by physical examination of the neonate..$^{13}$ All neonates were normally grown-that is their birthweights were between the 10th and 90th centiles for gestational maturity, gender, and race. Separate birthweight-gestational age curves were used for white Latin-American (Gibbs, unpublished data) and Anglo-American ${ }^{14}$ neonates.

The neonates were managed in accordance with our nursery's usual practices. Total parenteral nutrition was started as soon as clinically indicated. The basic regimen is shown in Table 1, but individual intakes were tailored to each neonate's requirement and metabolic tolerance in order to maximise caloric intake. All neonates received a fat emulsion (Intralipid, Cutter Laboratories, Emeryville, CA), beginning with a daily dose of $1 \mathrm{~g} / \mathrm{kg}$ infused at an even rate over 24 hours and increasing by $1 \mathrm{~g} / \mathrm{kg}$ a day every 24 hours to a maximum of $4 \mathrm{~g} / \mathrm{kg}$ a day. As long as a neonate required an arterial umbilical catheter for blood gas monitoring, total parenteral nutrition was administered via this route. After removal of the catheter peripheral veins were used. No enteral feedings were provided during the study. Amounts of blood removed for study or for clinical purposes were carefully tabulated and replaced by packed red blood cells whenever 7 to $10 \%$ of the baby's blood volume was estimated to have been removed.

Blood samples were obtained immediately before 
Table 1 Basic total parenteral nutrition regimen +

\begin{tabular}{lc}
\hline Component & Amount (per kg/day) \\
\hline Water & $100-130 \mathrm{ml}$ \\
Amino-acid (crystalline) & $2.5 \mathrm{~g}$ \\
Glucose & $\leq 20 \mathrm{~g}$ \\
Fat* & $4 \mathrm{~g}$ \\
Sodium & $3-7 \mathrm{mmol}$ \\
Potassium & $2-4 \mathrm{mmol}$ \\
Calcium & $1 \mathrm{mmol}$ \\
Magnesium & $0.5 \mathrm{mmol}$ \\
Chloride & $3-7 \mathrm{mmol}$ \\
Phosphate & $1-1.5 \mathrm{mmol}$ \\
Multivitamins $\dagger$ & $1 \mathrm{ml}$ \\
\hline
\end{tabular}

*Intralipid, Cutter Laboratories, Emeryville, CA; †MVI, USV Laboratories, Tuckahoe, NY.

$\ddagger$ Other vitamins (folic acid, B12, K) and cysteine were added after 10 days of total parenteral nutrition.

starting the lipid infusion and 4, 8, 12, and 24 hours after each change in dosage. Total plasma lipid concentrations were measured by a method based on the technique of Zöllner and Kirsch..$^{15}$ A commercial kit was used (Total Lipid Kit, Boehringer GMBh, Ingelheim, Germany) but the technique was modified to perform the assay on $5 \mu \mathrm{l}$ of plasma; a 5-point cholesterol standard curve was determined with each run of assays. Coefficients of variation were $6 \%$ intra-assay and $11 \%$ inter-assay. Total plasma triglycerides concentrations were measured by a method based on the technique of Eggstein and Kreutz. ${ }^{16}$ A commercial kit was used (Triglycerides Kit, fully enzymatic, Boehringer GMBh, Ingelheim, Germany) but the technique was modified to perform the assay on $10 \mu \mathrm{l}$ of plasma; a 4-point glycerol standard curve was determined with each run of assays. Coefficients of variation were $4 \%$ intra-assay and $6 \%$ inter-assay. This method carries the assumption that the plasma-free glycerol concentration is negligible. The fat emulsion however, contains $2.5 \mathrm{~g} / 100 \mathrm{ml}$ of glycerol as an osmotic agent. Since the ability of preterm neonates to metabolise glycerol has not been determined, it should not be assumed that the free glycerol concentration in plasma remains negligible. Free plasma glycerol concentrations were measured by a method based on the technique of Eggstein and Kreutz. ${ }^{16}$ A commercial kit was used (Triglyceride Kit, Boehringer GMBh, Ingelheim, Germany) but the technique was modified to perform the assay on $75 \mu \mathrm{l}$ of plasma and the saponification step was omitted; a 4-point glycerol standard curve was determined with each run of assays. Coefficients of variation were $4 \%$ intra-assay and $6 \%$ inter-assay. True plasma triglyceride concentrations were calculated by subtracting free glycerol concentration from total triglyceride concentration. Plasma free fatty acid concentrations were measured by the technique of Laurell and Tibbling, ${ }^{17}$ modified to perform the assay on $10 \mu \mathrm{l}$ of plasma. Coefficients of variation were $9 \%$ intra-assay and $14 \%$ inter-assay. All assays were performed in quadruplicate.

Results were analysed by comparing mean lipid concentrations at each time during infusion of lipids with the preinfusion level by the means of Student's $t$ test. Statistical significance was defined as $\mathbf{P}$ value less than $0 \cdot 05$.

\section{Results}

The characteristics of the study subjects are shown in Table 2. Ten neonates, 5 boys and 5 girls, were studied. Nine were of Latin-American ethic origin, and one was a white Anglo-American. Gestational ages ranged from 26 to 32 weeks; only one neonate was less than 28 weeks. Birthweights ranged from 960 to $1760 \mathrm{~g}$; all but 4 neonates weighed $1200 \mathrm{~g}$ or less. Postnatal ages at the beginning of the study ranged from 2 to 14 days; with the exception of one, all were younger than 7 days. Six babies had hyaline membrane disease, one of whom also had an intraventricular haemorrhage, and 1 baby each had perinatal asphyxia, patent ductus arteriosus and pneumothorax, transient tachypnoea and apnoea, and necrotising enterocolitis.

Plasma lipid levels varied greatly during lipid infusion. The single 26-week-gestation neonate

Table 2 Characteristics of the infants

\begin{tabular}{|c|c|c|c|c|c|}
\hline Case & Gender & $\begin{array}{l}\text { Birthweight } \\
(g)\end{array}$ & $\begin{array}{l}\text { Gestational age } \\
\text { (weeks) }\end{array}$ & $\begin{array}{l}\text { Postnatal age at start } \\
\text { of study (days) }\end{array}$ & Original diagnosis \\
\hline 1 & $\mathbf{F}$ & 1160 & 30 & 6 & Perinatal asphyxia, pneumothorax, patent ductus \\
\hline 2 & $\mathbf{F}$ & 960 & 28 & 6 & Hyaline membrane disease \\
\hline 3 & $\mathbf{F}$ & 1020 & 28 & 6 & Transient tachypnoea, apnoeic episodes \\
\hline 4 & $\mathbf{F}$ & 1700 & 32 & 14 & Suspected necrotising enterocolitis \\
\hline $5^{*}$ & $\mathbf{M}$ & 1760 & 32 & 4 & Hyaline membrane disease, pneumothorax \\
\hline 6 & $\mathbf{M}$ & 1020 & 26 & 2 & Hyaline membrane disease, intraventricular haemorrhage \\
\hline 7 & $\mathbf{M}$ & 1590 & 31 & $\overline{5}$ & Hyaline membrane disease \\
\hline 9 & $\mathbf{F}$ & 1200 & 30 & 2 & Hyaline membrane disease \\
\hline 10 & $\mathbf{M}$ & 1400 & 32 & $\overline{2}$ & Hyaline membrane disease \\
\hline
\end{tabular}

*This infant was white Anglo American; all the others were of Latin-American origin. 


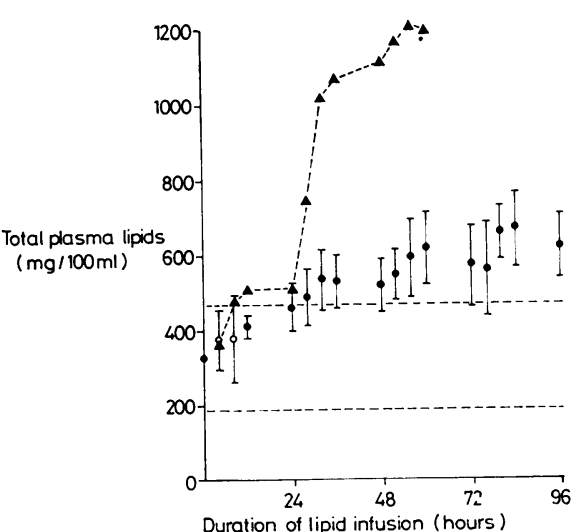

Fig. 1 Total plasma lipid concentrations in relation to duration of lipid infusion. Mean $\pm 2 S E$ are superimposed on the preinfusion range (mean $\pm 2 S D$ ). Closed circles indicate mean values statistically different from preinfusion mean. Triangles indicate values observed in an immature neonate (Case 6) with creamy plasma.

(Case 6) was the only one whose plasma became frankly creamy and lipid administration had to be stopped after 48 hours. All plasma lipid fractions in him were strikingly higher than in the other neonates. He was excluded from the statistical analysis, but his plasma lipid values are shown as triangles in the figures.

Preinfusion total plasma lipid concentrations averaged (mean \pm SE) $327 \pm 21.3 \mathrm{mg} / 100 \mathrm{ml}$ (range 268-495) (Fig. 1). While receiving only $1 \mathrm{~g} / \mathrm{kg}$ a day of lipids, most values remained within the preinfusion range. Twelve hours after the start of the infusion however, the mean concentration (413 \pm $16.0 \mathrm{mg} / 100 \mathrm{ml}$ ) was significantly higher than baseline. It remained higher thereafter. There seemed to be an increase in mean lipid concentrations after each dosage increase, but the differences between means were not statistically significant. With an infusion rate of $2 \mathrm{~g} / \mathrm{kg}$ a day, most values were higher than the preinfusion range. The highest recorded concentration was $986 \mathrm{mg} / 100 \mathrm{ml}$. In contrast (Case 6) had a total lipid concentration of $1200 \mathrm{mg} / 100 \mathrm{ml}$ when the infusion was stopped.

Preinfusion plasma free glycerol concentrations averaged $0.16 \pm 0.098 \mathrm{mmol} / 100 \mathrm{ml}$ (range $0 \cdot 05-0 \cdot 36)$ (Fig. 2). Free glycerol thus accounted for one-third of total triglycerides, hardly a negligible fraction. During lipid infusion, free glycerol levels followed the same trend as total plasma lipids. Most values remained within the preinfusion range as long as the rate of infusion did not exceed $1 \mathrm{~g} / \mathrm{kg}$ a day.

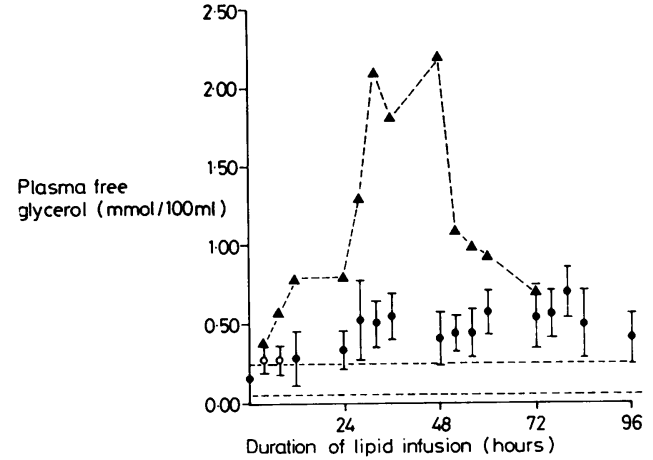

Fig. 2 Plasma free glycerol concentrations in relation to duration of lipid infusion. Symbols, see Fig. 1.

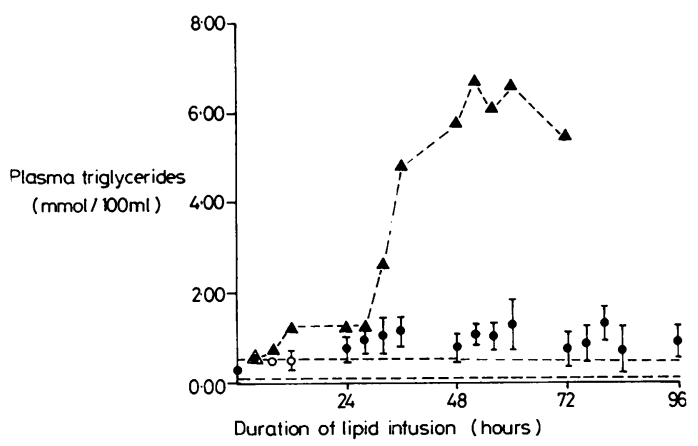

Fig. 3 Plasma true triglyceride concentrations in relation to duration of lipid infusion. Symbols, see Fig. 1.

Even then, 12 hours after the start of the infusion, the mean concentration $(0.26 \pm 0.093 \mathrm{mmol} / 100 \mathrm{ml})$ became significantly higher than baseline and remained higher thereafter. The highest recorded concentration was $1.01 \mathrm{mmol} / 100 \mathrm{ml}$. Interestingly, free glycerol continued to account for 28 to $44 \%$ of total plasma triglycerides. In Case 6 , free glycerol concentrations reached $2 \cdot 18 \mathrm{mmol} / 100 \mathrm{ml}$.

Preinfusion true plasma triglyceride concentrations averaged $0.30 \pm 0.031 \mathrm{mmol} / 100 \mathrm{ml}$ (range $0 \cdot 18-0.33$ ) (Fig. 3). Four hours after the start of lipid infusion, mean levels $(0.51 \pm 0.04 \mathrm{mmol} / 100$ $\mathrm{ml}$ ) were already significantly higher than baseline. Mean levels at 8 and 12 hours after start of the infusion were at the upper limit of preinfusion levels, but not statistically different. Later in the study, most levels were in excess of the baseline ranges. The highest recorded concentration was $2.5 \mathrm{mmol} / 100$ $\mathrm{ml}$. In Case 6, true triglyceride concentrations reached $6.58 \mathrm{mmol} / 100 \mathrm{ml}$. 


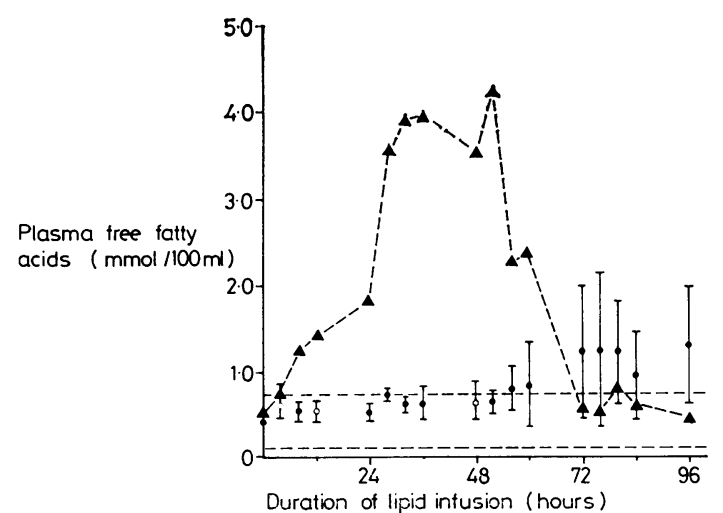

Fig. 4 Plasma free fatty acids concentrations in relation to duration of lipid infusion. Symbols, see Fig. 1 .

Preinfusion free fatty acid concentrations averaged $0.41 \pm 0.046 \mathrm{mmol} / 100 \mathrm{ml}$ (range $0.16-0.75$ ) (Fig. 4). With lipid infusion rates of 1 and $2 \mathrm{~g} / \mathrm{kg} \mathrm{a}$ day, most values remained within the preinfusion range, although mean levels were significantly higher than baseline from 24 hours on. Infusion rates of 3 and $4 \mathrm{~g} / \mathrm{kg}$ a day produced extremely variable free fatty acid concentrations. The highest recorded concentration was $4.31 \mathrm{mmol} / 100 \mathrm{ml}$ but only 2 out of 9 neonates had levels above $1.95 \mathrm{mmol} / 100 \mathrm{ml}$. In Case 6 free fatty acids concentrations reached $4.28 \mathrm{mmol} / 100 \mathrm{ml}$.

\section{Discussion}

The use of lipid emulsions with total and supplemental parenteral nutrition programmes for very low birthweight neonates has become widespread. The American Academy of Pediatrics has recently published recommendations regarding this practice. ${ }^{18}$ Many questions regarding optimal composition of lipid emulsions, proper dosage, method of administration, potential hazards, and metabolic consequences of their use remain unanswered. In particular the common practice of infusing the daily dose in less than 24 hours, thus resorting to higher fat intakes per unit of time, may not be the most appropriate to limit the risks of metabolic intolerance. With glucose infusions, the major factor limiting metabolic tolerance has been shown to be the amount of glucose administered per kilogram of body weight per unit of time..$^{19} \mathrm{~A}$ similar principle has been suggested to apply to amino-acid infusions. ${ }^{20}$ There is no reason to believe that fat infusions would deviate from this principle. Yet, most studies of fat emulsion tolerance in low birthweight neonates have involved bolus injections of
0.1 to $0.3 \mathrm{~g} / \mathrm{kg}^{238}$ or short-term infusions. ${ }^{457}$. commonly used technique is to infuse $1 \mathrm{~g} / \mathrm{kg}$ of fat emulsion in 4 hours $^{49}$ although this rate of infusiorf is equivalent to giving $0.25 \mathrm{~g} / \mathrm{kg}$ per hour. Deleteriou? effects of fat emulsions on oxygenation of red cell? have been shown to occur with infusions over 1 to hours at rates equivalent to 0.25 to $1 \mathrm{~g} / \mathrm{kg}$ per day. ${ }^{7}$. In clinical practice however, one usually does no\& exceed rates of $4 \mathrm{~g} / \mathrm{kg}$ per day or $0 \cdot 17 \mathrm{~g} / \mathrm{kg}$ per hour Studies performed under clinical conditions sugges? that plasma lipid concentrations are not much higher after 24 hours of lipid infusions than before the infusion. ${ }^{619}$ The clinical implications of much oह the available data are less than clear.

In this study we attempted to determine the effects of lipid infusions on the concentrations of various plasma lipid fractions in a routine clinicał situation. During lipid infusion, the plasma con? centrations of all fractions increased above the preinfusion values if $2 \mathrm{~g} / \mathrm{kg}$ per day or more of lipiक emulsion was used. There were no further significan? increases in plasma lipid levels when the infused dosage was increased to 3 and $4 \mathrm{~g} / \mathrm{kg}$ per day. At these higher infusion rates however, there werE్ considerable individual variations in plasma con ${ }^{\omega}$ centrations of all fractions measured. There arE many factors likely to affect plasma lipid values Gestational maturity, pre- and postnatal nutritionas status, birthweight, intercurrent illnesses, rate of lipiक infusion, and many other variables could be named ${ }_{\circ}^{\infty}$ It is worth mentioning that the only infant (Case 6 to develop hyperlipaemia of sufficient severity to require the study to be stopped was less than $2 z$ weeks of gestation. His plasma lipid levels were severalfold higher than those of any other infant and his plasma was frankly creamy on visual inspection? This is compatible with the recent report that suggests that lipoprotein lipase reserve, an enzyme needed to metabolise parenterally administered lipids, is limited in neonates less than 27 weeks of gestation compared with their more mature peers. ${ }^{21}$

Further investigations are needed to compare the effects of continuous versus interrupted infusions of lipids, to determine the optimal rates of infusion for neonates of various gestational ages, to search for ater easy method of monitoring plasma lipid levels, and to uncover the effects of hyperlipaemia on bilirubinu metabolism and oxygen diffusion in the lungs.

This study was partly supported by Cutte? Laboratories, Emeryville, California.

\section{References}

1 Hallberg D, Holm I, Obel A L, Schuberth O, Wretlind A. Fat emulsions for complete intravenous nutrition Postgrad MedJ 1967; 43: 307-16.

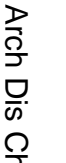


2 Gustafson A, Kjellmer I, Olegărd R, Victorin L $\mathbf{H}$. Nutrition in low-birthweight infants. I. Intravenous injection of fat emulsion. Acta Paediatr Scand 1972; 61: 149-58.

3 Olegård R, Gustafson A, Kjellmer I, Victorin L $\mathbf{H}$. Nutrition in low-birthweight infants. III. Lipolysis and free fatty acid elimination after intravenous administration of fat emulsion. Acta Paediatr Scand 1975; 64: 745-51.

4 Andrew G, Chan G, Schiff D. Lipid metabolism in the neonate. II. The effects of Intralipid infusion on plasma triglyceride and free fatty acid concentrations in the neonate. J Pediatr 1976; 88: 273-8.

5 Reid W D, Robinson H. Atherosclerosis and childhood: metabolic response to Intralipid infusions in the neonatal period. Adv Exp Med Biol 1977; 82: 201-3.

- Griffin E, Breckenridge W C, Kuksis A, Bryan M H, Angel A. Appearance and characterization of lipoprotein $X$ during continuous Intralipid infusions in the neonate. $J$ Clin Invest 1979; 64: 1703-12.

7 Sun S C, Ventura C, Verasestakul S. Effect of Intralipidinduced lipaemia on the arterial oxygen tension in preterm infants. Resuscitation 1978; 6: 265-70.

8 Gustafson A, Kjellmer I, Olegård R, Victorin L H. Nutrition in low-birth-weight infants. II. Repeated intravenous injections of fat emulsion. Acta Paediatr Scand 1974; 63: 177-82.

9 Pereira G R, Fox W W, Stanley C A, Baker L, Schwartz J G. Decreased oxygenation and hyperlipemia during intravenous fat infusions in premature infants. Pediatrics 1980; 66: 26-30.

10 Andrew G, Chan G, Schiff D. Lipid metabolism in the neonate. II. The effect of Intralipid on bilirubin binding in vitro and in vivo. J Pediatr 1976; 88: 279-84.

11 Friedman Z, Marks $\mathrm{K} \mathrm{H}$, Maisels M J, Thorson R, Naeye R. Effect of parenteral fat emulsions on the pulmonary and reticuloendothelial systems in the newborn infant. Pediatrics 1978; 61: 694-8.

12 Levene M I, Wigglesworth J S, Desai R. Pulmonary fat accumulation after Intralipid infusion in the preterm infant. Lancet 1980; ii: 815-9.
13 Dubowitz L M S, Dubowitz V, Goldberg C. Clinical assessment of gestational age in the newborn infant. J Pediatr 1970; 77: 1-10.

14 Freeman M G, Graves W L, Thompson R L. Indigent Negro and Caucasian birthweight-gestational age tables. Pediatrics 1970; 46: 9-15.

15 Zöllner N, Kirsch K. Über die quantitative Bestimmung von Lipoiden (Mikromethode) mittels der vielen natürlichen Lipoiden (allen bekannten Plasmalipoiden) gemeinsamen Sulfophosphovanillin-Reaktion. $Z$ Gesamte Exp Med 1962; 135: 545-61.

16 Eggstein M, Kreutz F H. Eine neue Bestimmung der Neutralfette im Blutserum und Gewebe. I. Prinzip, Durchführung und Besprechung der Methode. Klin Wochenschr 1966; 44: 262-7.

17 Laurell S, Tibbling G. Colorimetric micro-determination of free fatty acids in plasma. Clin Chim Acta 1967; 16: $57-62$.

18 American Academy of Pediatrics Committee on Nutrition. Use of intravenous fat emulsions in pediatric patients. Pediatrics 1981; 68: 738-43.

19 Dweck H S, Cassady G. Glucose intolerance in infants of very low birth-weight. I. Incidence of hyperglycemia in infants of birth weights 1,100 grams or less. Pediatrics 1974; 53: 189-95.

20 Brans Y W, Sumners J E, Dweck H S, Cassady G. Feeding the low birthweight infant: orally or parenterally? Preliminary results of a comparative study. Pediatrics $1974 ; 54: 15-22$.

${ }^{21}$ Dhanireddy $R$, Hamosh $M$, Sivasubramanian $K \mathbf{N}$, Chowdhry P, Scanlon J W, Hamosh P. Postheparin lipolytic activity and Intralipid clearance in very lowbirth-weight infants. J Pediatr 1981; 98: 617-22.

Correspondence to Dr Yves W Brans, Department of Pediatrics, University of Texas Health Science Center, 7703 Floyd Curl Drive, San Antonio, Texas 78284, USA.

Received 6 July 1982 